\title{
PEMULIAAN (BREEDING) ASAS-ASAS HUKUM PERJANJIAN DALAM PERJANJIAN LEASING DI INDONESIA
}

\author{
Siti Malikhatun Badriyah \\ Fakultas Hukum Universitas Diponegoro \\ E-mail: malikha_b@yahoo.com
}

\begin{abstract}
Leasing agreement is extremely useful for society, but there are many deviations from the principles of contract law and the principles of leasing in actual practices, so that is needed to make the breeding of the principles contract law. In the leasing agreement practice, there are some deviations from the principles of contract law and the leasing principles, so that they create inbalancing in the legal relations; the breeding of contract law principles becomes an important thing which must be done immediatly in order to have a fair and balancing legal relations; the principle of contract law as the result of breeding is the harmony principle as prismatic principles of contract. The harmony principles that integrated of the principle of the reasonableness/equity, laras, rukun, the balancing and the proportionality.
\end{abstract}

Key Word: breeding, the principle of contract law, financial, leasing

\section{A. Latar Belakang}

Leasing memberikan peluang menarik bagi pengusaha, karena mempunyai keunggulan-keunggulan sebagai alternatif pembiayaan di luar sistem perbankan, antara lain proses pengadaan peralatan modal relatif lebih cepat dan tidak memerlukan jaminan kebendaan, prosedurnya sederhana dan tidak ada keharusan melakukan studi kelayakan yang memakan waktu lama, sehingga posisi cash flow perusahaan akan lebih baik dan biayabiaya modal menjadi lebih murah dan menarik.

Hubungan hukum dalam leasing dasarnya adalah perjanjian. Perjanjian leasing tidak dikenal dalam Kitab Undang-undang Hukum Perdata (K.U.H. Perdata). Masuknya perjanjian leasing ke Indonesia, karena adanya asas kebebasan berkontrak (Pasal 1338 K.U.H. Perdata). Perjanjian ini tunduk pada K.U.H. Perdata berdasarkan Pasal 1319, yang menentukan bahwa semua perjanjian baik yang mempunyai suatu nama khusus, maupun yang tidak terkenal dengan suatu nama tertentu, tunduk pada peraturan umum yang termuat di dalam bab ini atau bab yang lalu.

Perjanjian leasing merupakan perjanjian jenis baru yang mandiri (sui generis). Perjanjian ini termasuk perjanjian innominaat, karena tidak diatur secara khusus dalam KUH. Perdata. Meskipun terdapat berbagai manfaat yang diperoleh dengan munculnya lembaga leasing dalam praktik dunia usaha, namun belum ada pranata hukum yang memadai yang dapat memberikan kepastian dan perlindungan hukum bagi para pihak yang terlibat, padahal dalam praktik leasing terdapat berbagai penyimpangan terhadap asas-asas hukum perjanjian, khususnya adanya ketidakseimbangan hubungan hukum antara pihak lessor dengan lessee.

Pengaturan mengenai leasing yang selama ini ada, hanya bersifat administratif dan perpajakan saja. Mengenai aspek keperdataannya, khususnya perjanjian yang antara lain mengatur hak dan kewajiban para pihak masih sangat kurang, oleh karenanya para pihak dapat menentukan sendiri. Padahal dalam perjanjian leasing para pihak menghadapi berbagai kemungkinan yang dapat menimbulkan kerugian, sehingga dapat menimbulkan persengketaan (konflik). Sementara, leasing ini berasal dari negara lain yaitu Amerika yang memiliki sistem hukum yang berbeda dengan Indonesia.

Dalam perjanjian leasing seringkali terdapat klausula-klausula yang menimbulkan kesewenang-wenangan dari salah satu pihak yang mempunyai bargaining potition kuat terhadap pihak lainnya. Bahkan dalam praktik, hal demikian berpotensi menimbulkan kerugian pada pihak lain. Menurut Radu M. Sembiring 
(2009), pembiayaan leasing menjadi penyebab kerugian konsumen terbesar sampai saat ini. Berdasarkan data pada Departemen Perdagangan di Surabaya, dalam 5 bulan sampai bulan Mei 2009 dari 35 kasus berdasarkan pengaduan masyarakat di Indonesia, leasing menempati urutan pertama penyebab kerugian konsumen. Dalam pelaksanaan leasing, seringkali objek leasing tidak hanya terbatas pada barang modal, tetapi leasing juga sering digunakan untuk penyediaan barang konsumsi, padahal seharusnya leasing hanya dapat dilakukan untuk pembiayaan barang modal. Penyimpangan juga terjadi dalam hal hak opsi yang mestinya dilakukan pada akhir perjanjian, tetapi dalam praktik, seringkali lessee harus sudah menggunakan hak opsi untuk membeli barang leasing pada awal perjanjian, yaitu bersamaan dengan penandatanganan perjanjian leasing. Pada salah satu perusahaan leasing di Semarang, bahkan ditentukan bahwa objek leasing sekaligus adalah sebagai objek jaminan fidusia untuk menjamin perjanjian leasing tersebut. Hal ini tidak sesuai dengan prinsip jaminan fidusia, karena untuk terjadinya jaminan fidusia, pemberi fidusia harus memiliki hak milik atas benda yang menjadi objek jaminan fidusia. Dalam leasing, hak milik atas barang yang menjadi obyek leasing baru beralih dari lessor kepada lessee apabila pada akhir perjanjian, lessee menggunakan hak opsi untuk membeli objek leasing yang bersangkutan.

Adanya penyimpangan dari asas-asas hukum perjanjian, serta munculnya berbagai kerancuan dalam praktik leasing, yang berpotensi menimbulkan sengketa di dalam kehidupan di masyarakat tersebut, maka sangat dibutuhkan adanya pemuliaan (breeding) asasasas hukum perjanjian, untuk lebih melengkapi asas-asas hukum perjanjian yang sudah ada untuk dapat diterapkan pada perjanjian leasing, agar dalam perjanjian leasing terdapat keseimbangan hubungan antara para pihak.

Dari uraian pada latar belakang, ada tiga permasalahan yang diajukan dalam penelitian ini, yang pertama, bagaimanakah hubungan hukum antara para pihak dan penerapan asas-asas hukum perjanjian dalam perjanjian leasing yang berkembang di dalam masyarakat?, kedua, mengapa pemuliaan terhadap asas-asas hukum perjanjian perlu dilakukan oleh para pihak dalam hubungan hukum pada perjanjian leasing di dalam masyarakat? dan ketiga, bagaimanakah asas-asas hukum perjanjian hasil pemuliaan yang dapat menciptakan hubungan hukum yang seimbang antara para pihak?

\section{B. Metode Penelitian}

Penelitian ini termasuk dalam tradisi penelitian kualitatif dengan operasionalisasi penelitian yang berparadigma alamiah (naturalistic paradigm). Paradigma penelitian yang digunakan adalah paradigma Constructivism atau lebih tepatnya Legal Constructivism, yang tergolong dalam kelompok paradigma nonpositivistik (Alfred North Whitehead, 1967).

Penelitian ini secara garis besar dapat dikelompokkan ke dalam ranah pendekatan sebagaimana dikemukakan Werner Menski yang disebut sebagai triangular concept of legal pluralism, yang memadukan pendekatan filosofis, normatif dan sosiologis. Dengan pendekatan legal pluralism ini hukum dipahami secara menyeluruh dengan pendekatan secara menyeluruh. Legal pluralism merupakan integrasi sempurna untuk memahami dan menegakkan hukum dalam masyarakat majemuk (plural). Pendekatan legal pluralism mengandalkan adanya pertautan antara state law (positive law), aspek kemasyarakatan (socio legal approach), dan natural law (moral/ethics/religion) (Werner Menski, 2006: 187).

Dalam penelitian ini dilakukan penelitian kepustakaan untuk memperoleh data sekunder dan penelitian lapangan untuk memperoleh data primer dengan sumber data utama adalah para pemangku kepentingan (stakeholders ) yang terkait langsung atau pihak-pihak yang memahami praktik perjanjian leasing yang terdiri dari informan kunci (key informan) dan informan lainnya yang ditentukan secara purposive dan snowball. Data dalam penelitian ini diperoleh melalui kegiatan-kegiatan observasi, interview visual, interpretasi dokumen (teks) dan material, serta personal experience ( Sanafiah Faisal1990: 80)

Dalam melakukan observasi peneliti sebagai instrumen utama (key instrument), karena peneliti sendiri langsung melakukan observasi partisipatif (participant observer), artinya ia menyatu dengan apa yang ditelitinya yang berakibat peneliti dekat dengan objek yang dikajinya. ( Robert Bogdan dan Steven J. Taylor1993: 31-32).

Teknik analisis data yang dipergunakan terhadap data primer, adalah teknik analisis data tipe Strauss dan J. Corbin (1990: 19), yaitu dengan menganalisis data sejak peneliti berada di 
lapangan (field). Setelah data terkumpul, kemudian diolah dan dianalisis dengan teknik induktif (Sudarto, 2002: 57) -kualitatif untuk menjawab problematika yang menjadi fokus studi penelitian ini. Langkah-langkah teknik analisis data penelitian ini mengikuti model interaktif analisis data, yang bergerak dalam tiga siklus kegiatan, yaitu: reduksi data, penyajian data, dan penarikan simpulan atau verifikasi (Mattew B. Miles and A. Michael Huberman, 1992: 22). Simpulan yang dimaksud bukanlah simpulan yang bersederajat dengan generalisasi. Terhadap data sekunder, dalam mencari kebenaran umum akan dilakukan dengan menggunakan logika deduktif, khususnya pada saat analisis awal (penggunaan teori-teori), namun tidak tertutup kemungkinan dilakukan analisis dengan menggunakan logika induktif terhadap kasuskasus perjanjian leasing yang telah terdokumentasi dalam bentuk hasil-hasil studi, pencatatan maupun hasil penelitian.

Keabsahan data dalam penelitian ini bertumpu pada "derajat keterpercayaan" (level of confidence) atau credibility (Lexy Moleong, 1996: 173) melalui teknik pemeriksaan keabsahan ketekunan pengamatan dan triangulasi. (Norman K. Denzin dan Y. Vonna S. Lincoln, 1994: 1-3).

\section{Hasil penelitian dan Pembahasan}

1. Asas Hukum Perjanjian dalam Sistem Hukum Nasional Indonesia

Asas hukum bukanlah suatu peraturan, namun seperti yang dikatakan oleh Scholten bahwa hukum tidak dapat dipahami dengan baik tanpa asas-asas (doch geen rechts is te begrijpen zonder die beginselen) (Satjipto Rahardjo 2006: 128). Asas merupakan pokok-pokok pikiran yang melandasi dan melatarbelakangi setiap ketentuan perundang-undangan maupun putusan pengadilan di dalam sistem hukum. Asas hukum mempunyai dua landasan, yaitu: pertama, asas hukum itu berakar dalam kenyataan masyarakat dan kedua, pada nilai-nilai yang dipilih sebagai pedoman oleh kehidupan bersama. Penyatuan faktor riil dan ideal hukum ini merupakan fungsi asas hukum (Nieuwenhuis dalam Sudikno Mertokusumo, 1996:6). Fungsi asas hukum dalam hukum menurut Klanderman, bersifat mengesahkan dan mempunyai pengaruh normatif dan mengikat para pihak. Mengenai fungsi asas hukum, J.J.H. Bruggink mengemukakan bahwa asas hukum mempunyai fungsi ganda yaitu sebagai fondasi dari sistem hukum positif dan sebagai batu uji kritis terhadap sistem hukum positif (J.J.H. Bruggink, 1999: hlm. 133).

Menurut Paton, asas hukum merupakan "jantungnya" peraturan hukum, karena: pertama, asas hukum merupakan landasan yang paling luas bagi lahirnya suatu peraturan hukum; kedua, asas hukum juga dapat disebut sebagai alasan bagi lahirnya peraturan hukum (rasio legis) dari peraturan hukum. Selanjutnya Paton mengemukakan bahwa asas hukum itu mengawal dan memberi daya hidup (nourishment) kepada hukum dan bagianbagian atau bidang-bidang dari hukum.

Pada setiap Negara terdapat asas atau norma tertinggi sebagai asas yang menjadi sumber dari semua asas hukum, norma hukum yang berlaku di Negara yang bersangkutan yang disebut grundnorm, yang merupakan sumber berlakunya hukum tertinggi dan terakhir (source of the source), memberikan pertanggungjawaban kenapa hukum harus dilaksanakan, kepatuhan terhadapnya tidak terdapat sanksi, diterima masyarakat secara aksiomatis. Grundnorm yang dimiliki Indonesia adalah Pancasila. Pancasila menjadi falsafah bangsa, pandangan hidup dan dasar Negara Indonesia. Pancasila menjadi landasan bagi bangsa Indonesia dalam bertindak atau berperilaku. Asas hukum menjadi landasan bagi asas-asas hukum, termasuk asas hukum perjanjian. Asas pokok hukum perjanjian di Indonesia meliputi Asas konsensualisme Pasal 1320 ayat (1) KUH Perdata, asas kebebasan berkontrak (Pasal 1338 ayat 1) KUH Perdata, asas kekuatan mengikat perjanjian (pacta sunt servanda) Pasal 1320 dan Pasal 1338 ayat 1 KUH Perdata. Asas hukum perjanjian ini seharusnya menjadi landasan dalam setiap perjanjian di Indonesia, termasuk perjanjian leasing.

2. Hubungan Hukum dalam Perjanjian Leasing

Sewa Guna Usaha (leasing) adalah kegiatan pembiayaan dalam bentuk penyediaan barang modal baik secara sewa guna usaha dengan hak opsi (finance lease) maupun sewa guna usaha tanpa hak opsi 
(operating lease) untuk digunakan oleh Penyewa Guna Usaha (lessee) selama jangka waktu tertentu berdasarkan pembayaran secara berkala (Peraturan Menteri Keuangan Nomor 84/PMK.012/2006 Tentang Perusahaan Pembiayaan jo. Pasal 1 angka 5 Peraturan Presiden Nomor 9 Tahun 2009).

beberapa unsur yang harus terdapat dalam leasing yaitu :

a. Lessor yaitu pihak yang menyediakan barang-barang modal untuk lessee, merupakan perusahaan pembiayaan yang mendapat izin dari Departemen Keuangan;

b. Lessee yaitu pihak yang mendapatkan pembiayaan dari lessor atau pihakpihak yang membutuhkan/memakai barang-barang modal.

c. Objek leasing yaitu barang-barang yang menjadi objek perjanjian leasing yang meliputi segala macam barang modal mulai dari yang berteknologi tinggi hingga teknologi menengah ataupun keperluan kantor.

d. Pembayaran uang sewa yaitu secara berkala dalam jangka waktu tertentu yang bisa dilakukan setiap bulan, setiap kuartal, atau setiap setengah tahun sekali.

e. Nilai sisa (residual value) yang ditentukan sebelum kontrak dimulai.

f. Adanya hak opsi bagi lessee pada akhir masa leasing, yang dalam hal ini lessee mempunyai hak untuk menentukan apakah lessee ingin membeli barang tersebut dengan harga sebesar nilai sisa atau mengembalikan pada lessor.

g. Lease Term adalah suatu periode perjanjian leasing.

Perjanjian leasing pada umumnya dibuat dalam bentuk baku. Menurut Sudikno Mertokusumo (1990:4) perjanjian standar atau perjanjian baku adalah perjanjian yang isinya ditentukan secara a priori oleh pihak yang menyusun, sehingga pihak adherent merasa tidak bebas kehendaknya, karena tidak ada persesuaian kehendak dan merasa ada pada pihak yang lemah. Perjanjian leasing disusun secara sepihak oleh lessee.

Jenis leasing pada prinsipnya apabila dilihat dari sisi risiko ekonomis terhadap benda yang menjadi objek leasing menurut Siti Ismijatie (1998: 14) ada dua jenis leasing, yaitu sewa guna usaha dengan hak opsi (financial lease). dan sewa guna usaha tanpa hak opsi (operating lease). Pada sewa guna usaha dengan hak opsi risiko ekonomis atas objek lease ada pada lessee, sedangkan pada sewa guna usaha tanpa hak opsi risiko ekonomis ada pada lessor.

Dengan mengacu tulisan Beckman dan Joosen menurut Siti Ismijati Jenie, terdapat penekanan bahwa dalam financial leaes, risiko atas kemungkinan timbulnya penurunan nilai benda yang merupakan objek leasing ditanggung sepenuhnya oleh lessee, meskipun hak milik atas barang tersebut secara yuridis ada pada lessor. Dengan kata lain, pihak lessee memperoleh hak untuk memakai suatu benda dengan sekaligus harus menanggung risiko ekonomis atas benda tersebut. Risiko ekonomis merupakan suatu unsur yang terkandung dalam pengertian hak milik. Pemilik suatu benda dengan sendirinya senantiasa harus menanggung risiko ekonomis atas benda tersebut. Berdasarkan hal tersebut di atas, dapat dikatakan bahwa lessee di dalam financial lease seolah-oleh memperoleh hak milik atas benda yang menjadi objek lease tersebut, karena lessee harus menanggung risiko ekonomis atas benda tersebut, sedangkan hak milik yang berada pada lessor hanya sekedar alat untuk menjamin pemenuhan perikatan lessee kepada lessor. Hak milik ini bukan hak milik dalam arti yang sebenarnya, sebab di dalamnya tidak lagi terkandung unsur "risiko ekonomis". Dapat dikatakan bahwa sebenarnya financial leasing, juga merupakan suatu cara untuk melakukan investasi bagi usaha yang menggunakan lembaga ini untuk memperoleh alat-alat produksi maupun barang-barang modal.

Dari Pasal 1 huruf c jo. Pasal 3 ayat (1) Peraturan Menteri Keuangan Nomor 84/PMK.012/2006 jo. Pasal 2 ayat (1) Keputusan Menteri Keuangan Nomor 1169/KMK.01/1991 yang mengatur tentang pengertian leasing dan tentang kegiatan usaha dapat dilihat bahwa di Indonesia leasing dibedakan menjadi dua yaitu: 1) Sewa Guna Usaha (leasing) dengan hak opsi (finance

Pemuliaan (Breeding) Asas-Asas... 50 
lease); 2) Sewa Guna Usaha (leasing) tanpa hak opsi (operating lease)

3. Konsep Pemuliaan Asas-asas Hukum Perjanjian

Pemuliaan berasal dari istilah dalam bahasa Inggris breeding, yang merupakan penerapan biologi, terutama genetika, dalam bidang pertanian untuk memperbaiki produksi atau kualitas. Ilmu ini relatif baru dan lahir sebagai implikasi berkembangnya pemahaman manusia atas asas-asas pewarisan sifat secara genetis. Ilmu ini berusaha menjelaskan dan menerapkan prinsip-prinsip genetika (dengan bantuan cabang-cabang biologi lain) dalam kegiatan perbaikan genetik serta penangkaran tanaman atau hewan budidaya. Ilmu pemuliaan telah diterapkan di semua bidang pertanian, baik tanaman budidaya serta hortikultura (disebut pemuliaan tanaman), peternakan (disebut pemuliaan ternak), kehutanan, maupun perikanan. Produk hasil pemuliaan dikenal sebagai kultivar atau varietas (untuk tanaman), strain, galur, atau populasi seleksi (untuk ternak). (http//id.wikipedia.org.)

Istilah pemuliaan dalam penelitian ini adalah pengembangan asas-asas hukum perjanjian dari asas-asas hukum perjanjian yang telah ada diintegrasikan dengan asas-asas hukum lain, sehingga menjadi asas-asas hukum perjanjian yang lebih kompleks, khususnya dalam penerapannya pada perjanjian leasing.

4. Pemuliaan Terhadap Asas-asas Hukum Perjanjian dalam Hubungan Hukum Antara Para Pihak pada Perjanjian Leasing

a. Kesenjangan Perjanjian Leasing Eksisting dan Ideal

Dalam praktik perjanjian leasing menunjukkan adanya kesenjangan antara perjanjian leasing ideal dengan eksisiting, yang dapat digambarkan dalam tabel-tabel berikut.

Tabel Konstruksi Perjanjian Leasing Ideal

\begin{tabular}{|c|l|}
\hline No & \multicolumn{1}{|c|}{ Konstruksi Perjanjian Leasing } \\
\hline 1 & $\begin{array}{l}\text { Dasar: Asas-asas Hukum Perjanjian yaitu asas konsensualisme (Pasal 1320 ayat (1) KUH } \\
\text { Perdata), asas kebebasan berkontrak Pasal 1338 ayat (1) KUH Perdata), asas kekuatan } \\
\text { mengikat perjanjian (pacta sunt servanda) (Pasal 1338 ayat (1)) }\end{array}$ \\
\hline 2 & Subjek: lessor dan lessee. Antara kedua pihak terdapat hubungan hukum yang seimbang. \\
\hline 3 & $\begin{array}{l}\text { Tujuan: terwujudnya hubungan hukum yang seimbang antara para pihak, berorientasi pada } \\
\text { kepentingan bersama, tercermin dari hak dan kewajiban antara para pihak yang berimbang } \\
\text { dalam semua tahap perjanjian }\end{array}$ \\
\hline 4 & $\begin{array}{l}\text { Proses: pada setiap tahap baik tahap pra kontraktual, kontraktual, maupun post kontraktual } \\
\text { benar-benar berlandaskan pada asas-asas hukum perjanjian. }\end{array}$ \\
\hline 5 & $\begin{array}{l}\text { Substansi: } \\
\text { a. Subjek: lessor dan lessee adalah pelaku usaha, bukan konsumen karena prinsip leasing } \\
\text { adalah penyediaan barang modal untuk keperluan usaha } \\
\text { b. Objek: barang modal bukan barang konsumsi } \\
\text { c. Metode pembayaran: angsuran } \\
\text { d. Jangka waktu perjanjian (lease term): dapat dibatalkan salah satu pihak bukan hanya lessor } \\
\text { tetapi juga lessee hanya dengan putusan hakim, dimungkinkan negosiasi ulang } \\
\text { e. Hak opsi: diberikan pada akhir perjanjian sesuai dengan prinsip leasing } \\
\text { f. Hak dan kewajiban: seimbang } \\
\text { g. Residual value (nilai sisa) }\end{array}$ \\
\hline
\end{tabular}




\begin{tabular}{|c|l|}
\hline 6 & Pengawasan: \\
& $\begin{array}{l}\text { a. Diatur oleh undang-undang khusus tentang perjanjian leasing } \\
\text { b. Pengawasan Publik yang efektif, terdapat lembaga pengawas yang terdiri dari unsur } \\
\text { tokoh masyarakat, pihak swasta dan pemerintah }\end{array}$ \\
\hline 7 & $\begin{array}{l}\text { Consekuensi: Perjanjian leasing yang berdasarkan asas-asas hukum perjanjian, sehingga } \\
\text { preventif maupun represif } \\
\text { dengan perjanjian leasing dapat menciptakan hubungan hukum yang seimbang antara para } \\
\text { pihak }\end{array}$ \\
\hline
\end{tabular}

Tabel 2

Konstruksi Perjanjian Leasing dalam Peraturan Perundang-undangan

\begin{tabular}{|c|l|}
\hline No & \multicolumn{1}{c|}{ Konstruksi Perjanjian Leasing } \\
\hline 1 & $\begin{array}{l}\text { Dasar: Asas-asas Hukum Perjanjian, yaitu asas konsensualisme (Pasal 1320 ayat (1) KUH } \\
\text { Perdata), asas kebebasan berkontrak Pasal 1338 ayat (1) KUH Perdata), asas pacta sunt } \\
\text { servanda (Pasal 1338 ayat (1) KUH Perdata). }\end{array}$ \\
\hline 2 & $\begin{array}{l}\text { Subjek: lessor dan lessee. Antara kedua pihak terdapat hubungan hukum yang seimbang } \\
\text { (sebagai mitra) bukan subordinasi }\end{array}$ \\
\hline 3 & Tujuan: terwujudnya hubungan hukum yang seimbang antara para pihak \\
\hline 4 & $\begin{array}{l}\text { Proses: tidak ada pengaturan secara khusus, hanya disebutkan bahwa perjanjian leasing dibuat } \\
\text { dalam bentuk tertulis }\end{array}$ \\
\hline 5 & $\begin{array}{l}\text { Substansi: } \\
\text { a. Subjek: lessor dan lessee adalah pelaku usaha } \\
\text { b. Objek: barang modal } \\
\text { c. Metode pembayaran: angsuran } \\
\text { d. Jangka waktu perjanjian (lease term): tidak dapat dibatalkan secara sewenang-wenang } \\
\text { e. Hak opsi: pada akhir perjanjian } \\
\text { f. Hak dan kewajiban: Belum ada peraturan khusus yang mengatur perjanjian leasing, } \\
\text { sehingga hak dan kewajiban para pihak dalam perjanjian tidak secara tegas ditemukan } \\
\text { dalam satu peraturan, tetapi tersirat dari berbagai peraturan perundang-undangan }\end{array}$ \\
\hline 6 & \begin{tabular}{l} 
g. Residual value (nilai sisa) \\
Kengawasan: \\
konsekuensi: kurang memberikan kepastian dan perlindungan hukum terhadap para pihak, \\
prinsip leasing dan kerancuan-kerancuan. \\
b. Belum ada undang-undang khusus tentang perjanjian leasing \\
\hline 6
\end{tabular} \\
\hline
\end{tabular}


Tabel 3

\section{Konstruksi Existing Perjanjian Leasing dalam Praktik}

\begin{tabular}{|c|c|}
\hline No & Konstruksi Perjanjian Leasing \\
\hline 1 & $\begin{array}{l}\text { Dasar: Asas-asas Hukum Perjanjian, yaitu asas konsensualisme (Pasal } 1320 \text { ayat (1) KUH } \\
\text { Perdata), asas kebebasan berkontrak Pasal } 1338 \text { ayat (1) KUH Perdata), asas pacta sunt } \\
\text { servanda (Pasal } 1338 \text { ayat (1) KUH Perdata). }\end{array}$ \\
\hline 2 & Subjek: lessor dan lessee. Antara kedua pihak terdapat hubungan hukum yang tidak seimbang. \\
\hline 3 & $\begin{array}{l}\text { Tujuan: belum mencerminkan hubungan hukum yang seimbang antara para pihak, lebih pada } \\
\text { profit oriented, tercermin dari hak dan kewajiban antara para pihak yang tidak berimbang } \\
\text { dalam semua tahap perjanjian }\end{array}$ \\
\hline 4 & $\begin{array}{l}\text { Proses: pada setiap tahap baik tahap para kontraktual, kontraktual, maupun post kontraktual } \\
\text { tidak sesuai dengan asas-asas hukum perjanjian, bahkan terdapat ketidakseimbangan } \\
\text { hubungan hukum, penyimpangan-penyimpangan terhadap asas-asas hukum perjanjian }\end{array}$ \\
\hline 5 & $\begin{array}{l}\text { Substansi: } \\
\text { a. Subjek: lessor dan lessee. Lessee tidak selalu pelaku usaha, bisa juga konsumen } \\
\text { b. Objek: barang modal dan barang konsumsi } \\
\text { c. Metode pembayaran: angsuran } \\
\text { d. Jangka waktu perjanjian (lease term): dapat dibatalkan secara sewenang-wenang oleh } \\
\text { pihak lessor } \\
\text { e. Hak opsi: sering diberikan pada awal perjanjian } \\
\text { f. Hak dan kewajiban: tidak seimbang } \\
\text { g. Residual value (nilai sisa) }\end{array}$ \\
\hline 6 & $\begin{array}{l}\text { Pengawasan: } \\
\text { a. Belum ada undang-undang khusus tentang perjanjian leasing } \\
\text { b. Pengawasan Publik belum efektif } \\
\text { c. Campur tangan negara belum maksimal, karena belum menjangkau pengawasan kontrak } \\
\text { leasing, baru pada tataran administratif dan perpajakan. }\end{array}$ \\
\hline 7 & $\begin{array}{l}\text { Konsekuensi: Terdapat berbagai penyimpangan terhadap asas-asas hukum perjanjian dan } \\
\text { terdapat praktik perjanjian leasing yang menciptakan hubungan hukum yang tidak seimbang } \\
\text { antara para pihak serta berbagai kerancuan. }\end{array}$ \\
\hline
\end{tabular}

Perjanjian leasing secara filosofis, normatif maupun sosiologis berpotensi untuk menimbulkan penyimpangan-penyimpangan, yang dapat digambarkan dengan Teori Bekerjanya Hukum oleh William J. Chambliss dan Robert B. Seidman. Faktor yang dapat mempengaruhi bekerjanya hukum dalam masyarakat khususnya di bidang pelaksanaan perjanjian leasing:

(1) Faktor filosofis, yang menyangkut asas-

Yustisia Vol.1 No.2 Mei - Agustus 2012 asas, nilai-nilai. Dalam praktik perjanjian leasing terdapat berbagai penyimpangan terhadap asas-asas hukum perjanjian, baik asas konsensualisme, asas kebebasan berkontrak dan kekuatan mengikat perjanjian (asas pacta sunt sernvanda) serta penyimpangan terhadap prinsip-prinsip leasing.

(2) Faktor yang bersifat normatif; pembuatan peraturan perundang-undangan); Masuknya 
leasing ke Indonesia lebih didasarkan pada pertimbangan ekonomi. Undang-undang yang khusus mengatur tentang perjanjian leasing di Indonesia belum ada.

(3) Faktor Penegakannya (empiris/sosiologis) (para pihak dan peranan pemerintah). Faktor yang bersifat sosiologis (menyangkut pertimbangan ekonomis serta kultur hukum pelaku bisnis dari role occupant). Perjanjian yang menjadi dasar hubungan hukum antara para pihak dalam perjanjian leasing dibuat dalam bentuk baku, dengan pertimbangan bagi lessor lebih efisien karena dapat menghemat biaya, waktu dan tenaga. Di samping itu, dalam hal ini lessor dapat menentukan klausula-klausula perjanjian yang menguntungkan dirinya, dapat mengantisipasi kemungkinan kerugian di kemudian hari dan dapat menjamin keamanan pembiayaan yang dilakukannya. Pada pihak lain, lessee berdasarkan pertimbangan untuk dapat memperoleh barang modal dengan cepat dan biaya murah, tidak terlalu memperhatikan formalitas perjanjian. Terlebih lagi dalam hal pemakai jasa pembiayaan bukan pelaku usaha, pada saat ini dalam masyarakat makin berkembang sikap masyarakat yang makin konsumtif. Adanya mental yang ingin mencapai tujuan dengan cepat dengan cara yang mudah tanpa pertimbangan panjang sesuai dengan yang dikatakan oleh Kuntjaraningrat sebagai mental menerabas.

Melalui teori interaksionalis simbolik tersebut, dapat ditelusuri makna-makna tersembunyi dibalik subjek dalam penegakan hukum. Perilaku subjek dalam penegakan hukum, selalu ditentukan oleh berbagai disiplin yang mengenai mereka, yang oleh Chambliss dan Seidman dinyatakan sebagai hasil resultante. Kesemua faktor tersebut pada akhirnya mangakibatkan munculnya ketidakseimbangan hubungan antara lessor dan lessee, sehingga berakibat terjadinya penyimpangan terhadap asasasas hukum perjanjian, dan terdapat kerancuankerancuan dalam praktik perjanjian leasing.

5. Pemuliaan Asas-asas Hukum Perjanjian Berbasis Pancasila Sebagai Hukum Prismatik

Dalam Stufenbautheori dari Hans Kelsen dikemukakan bahwa keseluruhan hukum positif tersusun dalam sebuah hierarki logikal. Pada setiap negara selalu terdapat asas atau norma tertinggi sebagai asas yang menjadi sumber bagi semua asas hukum, norma hukum, dan hukum yang berlaku di negara yang bersangkutan, yang disebut dengan Grundnorm. Paton (dalam Moempoeni Moelatingsih: 14-16) mengemukakan bahwa Grundnorm yang dimiliki Indonesia adalah Pancasila yang pada dasarnya memiliki multifungsi bagi bangsa Indonesia yaitu sebagai pandangan hidup, ideologi bangsa dan dasar negara. Sebagai konsekuensinya dalam mengadakan pemuliaan terhadap asas-asas hukum perjanjian juga harus berlandaskan pada asas-asas yang terkandung di dalam Pancasila.

Menurut Teori Hukum Responsif dari

Nonet dan Selznik (dalam A.A.G. Peters, Koesriani 158-183), hukum sebagai fasilitator dari respon terhadap kebutuhan-kebutuhan sosial dan aspirasi-aspirasi sosial. Tipe hukum responsif berasal dari suatu hasrat untuk membuat hukum lebih bertujuan di dalam melayani manusia dan institusi-institusi untuk mencapai, tidak hanya keadilan yang formal, tetapi juga keadilan yang substantif. Hukum responsif yang dicita-citakan menuntut suatu penafsiran yang lebih luwes yang melihat aturan sebagai terikat pada problem dan konteks khusus, dan mencoba untuk mengidentifikasi nilai-nilai yang dipertaruhkan dalam perlindungan prosedural. Efeknya adalah untuk memungkinkan suatu cara penyelesaian secara integratif.

Dalam Konsep Hukum Progresif dari Satjipto Rahardjo ( 2009: 47-48),pada dasarnya hukum itu adalah untuk manusia, hukum progresif mempunyai tujuan besar berupa kesejahteraan dan kebahagiaan manusia, maka hukum selalu berada pada status law in the making. Hukum tidak ada untuk dirinya sendiri dan tidak bersifat final, sehingga apabila hukum itu tidak memberikan jaminan perlindungan hukum bagi manusia, maka harus dilakukan perubahan. Masyarakat progresif menurut Sir Henry Maine (dalam Lili Rasyidi, 1991: 48) adalah masyarakat yang mampu mengembangkan hukum melalui tiga cara yaitu fiksi, equity dan perundang-undangan. Volgeist bukan sesuatu yang mistik, karena perjalanan kehidupan masyarakat terdapat perkembangan dari situasi yang ditentukan oleh status kepada penggunaan perjanjian. Cara berhukum progresif tidak hanya mengedepankan aturan (rule), tetapi juga perilaku (behavior). Berhukum tidak hanya tekstual, melainkan juga kontekstual.

Dalam pembangunan hukum hendaknya dilihat secara utuh melalui pendekatan holistik, mengingat hukum bukan sekedar formalitas yang hanya berurusan dengan soal-soal normatif, melainkan unsur 
kultur pun perlu mendapat perhatian di samping struktur dan substansinya. Dengan demikian hukum memiliki keberlakuan: 1) Faktual /empiris, artinya dipatuhi dan ditegakkan; 2) Normatif/formal, yaitu kaidahnya cocok dalam sistem hukum hierarkhis; 3) Evaluatif, yaitu diterima dan benar (bermakna) serta memiliki sifat mewajibkan karena isinya (J.J.H. Bruggink, dalam Esmi Warassih, 2005: 175).

Hal tersebut penting dicermati mengingat problema yang dihadapi dalam pembangunan hukum di Indonesia pada masa mendatang adalah tidak semata-mata terletak pada masalah-masalah kepatuhan hukum (an sich) tetapi juga terletak pada bagaimana agar hukum benar-benar dapat mewujudkan tiga hal pokok sebagaimana dikemukakan oleh Gustav Radbruch (dalam Satipto Rahardjo, 2006: 137138) mengenai cita hukum (idée des rechts) yang ditopang oleh tiga nilai dasar (grundwerten) yaitu keadilan (gerechtigkeit), kemanfaatan (zweckmaeszigkeit) dan kepastian hukum (rechtssicherkeit). Hukum seharusnya dapat mewujudkan tiga nilai dasar tersebut secara proporsional, namun seringkali tiga nilai tersebut berada dalam suatu ketegangan (spannungsverhaeltnis). Dalam hal terjadi demikian, maka keadilan yang seharusnya diutamakan tanpa mengabaikan kemanfaatan dan kepastian hukumnya.

Untuk menjelaskan berbagai fenomena dalam kehidupan masyarakat dalam situasi global yang makin kompleks, maka ketiga cara (normatif, sosiologis, filosofis) tersebut di atas harus digunakan secara bersama-sama dan proporsional di dalam ilmu hukum. Pendekatan ini merupakan pendekatan baru yang diperkenalkan oleh Werner Menski yang disebut sebagai triangular concept of legal pluralism 2006: 187). Legal pluralism merupakan integrasi sempurna untuk memahami dan menegakkan hukum dalam masyarakat majemuk (plural). Pendekatan legal pluralism mengandalkan adanya pertautan antara state law (positive law), aspek kemasyarakatan (socio legal approach), dan natural law (moral/ethic/religion).

Kondisi hukum dan perekonomian Indonesia yang beragam sangat sesuai dengan kondisi masyarakat prismatik yang diuraikan oleh Fred W. Riggs dengan menggunakan dikhotomi kelima dari Talcott Parsons sebagai konsepsi dasar untuk mengembangkan teorinya tentang masyarakat prismatik. Riggs membedakan antara "fused types of society" yang merupakan masyarakat yang utuh dengan "diffracted types of society" yang ditandai oleh pembedaan dan pemisahan fungsi-fungsi yang lengkap. Masyarakat yang "fused" prototipenya adalah kekerabatan (paguyuban), yang memenuhi hampir semua peranan dan fungsi. Pada masyarakat yang diffracted maka segenap unsur-unsurnya mempunyai struktur yang spesifik (patembayan), ada sub sistem ekonomi, sub sistem politik, sub sistem pendidikan, sub sistem hukum dan seterusnya, yang masing-masing mempunyai organisasi sendiri-sendiri dan menjalankan fungsi dari tiaptiap sub sistem tersebut. Sub sistem-sub sistem tersebut masing-masing memiliki derajat otonomi tertentu akan tetapi juga bersifat tergantung. Dengan kerangka ini Fred W. Riggs mengintroduksikan konsepsi masyarakat prismatik atau "prismatic type of society".

Konsep masyarakat prismatik merupakan hasil identifikasi Riggs terhadap pilihan kombinatif atau jalan tengah atas nilai sosial paguyuban dan nilai sosial patembayan seperti yang dikemukakan oleh Hoogvelt (1985: 87-91).

Beberapa nilai- khas yang kemudian mengkristalkan tujuan, dasar, cita hukum dan norma dasar negara Indonesia, yang kemudian melahirkan sistem hukum nasional Indonesia yang khas pula antara lain meliputi kombinasi dari:

a. Nilai kepentingan: antara Individualisme dan Kolektivisme;

b. Konsepsi negara hukum: antara Rechtsstaat dan the Rule of Law;

c. Hukum dan Masyarakat: antara Alat Pembangunan dan Cermin Masyarakat;

d. Negara dan Agama: Religius Nation State.

Dalam penelitian ini, kombinasi nilai sosial yang perlu dipertimbangkan adalah kombinasi antara pembentukan nilai kepentingan, yaitu antara individualisme dan kolektivisme.

Berdasarkan Teori Prismatik dari Riggs , dalam pemuliaan (breeding) asas-asas hukum peranjian dilakukan pengolahan antara asas-asas hukum perjanjian (asas konsensualisme, asas kebebasan berkontrak, asas pacta sunt servanda) dengan asas-asas hukum lain yaitu 
asas hukum adat (rukun, patut, laras), asas hukum ekonomi (asas keseimbangan kepentingan, asas pengawasan publik, asas camput tangan negara), nilai-nilai yang hidup dalam masyarakat, serta UNIDROIT Principles dengan mendasarkan pada Pancasila sebagai falsafah dan dasar negara Indonesia maka dihasilkan asas hukum perjanjian prismatik yaitu asas harmoni.

\section{Ragaan Proses Pemuliaan Asas Hukum Perjanjian}

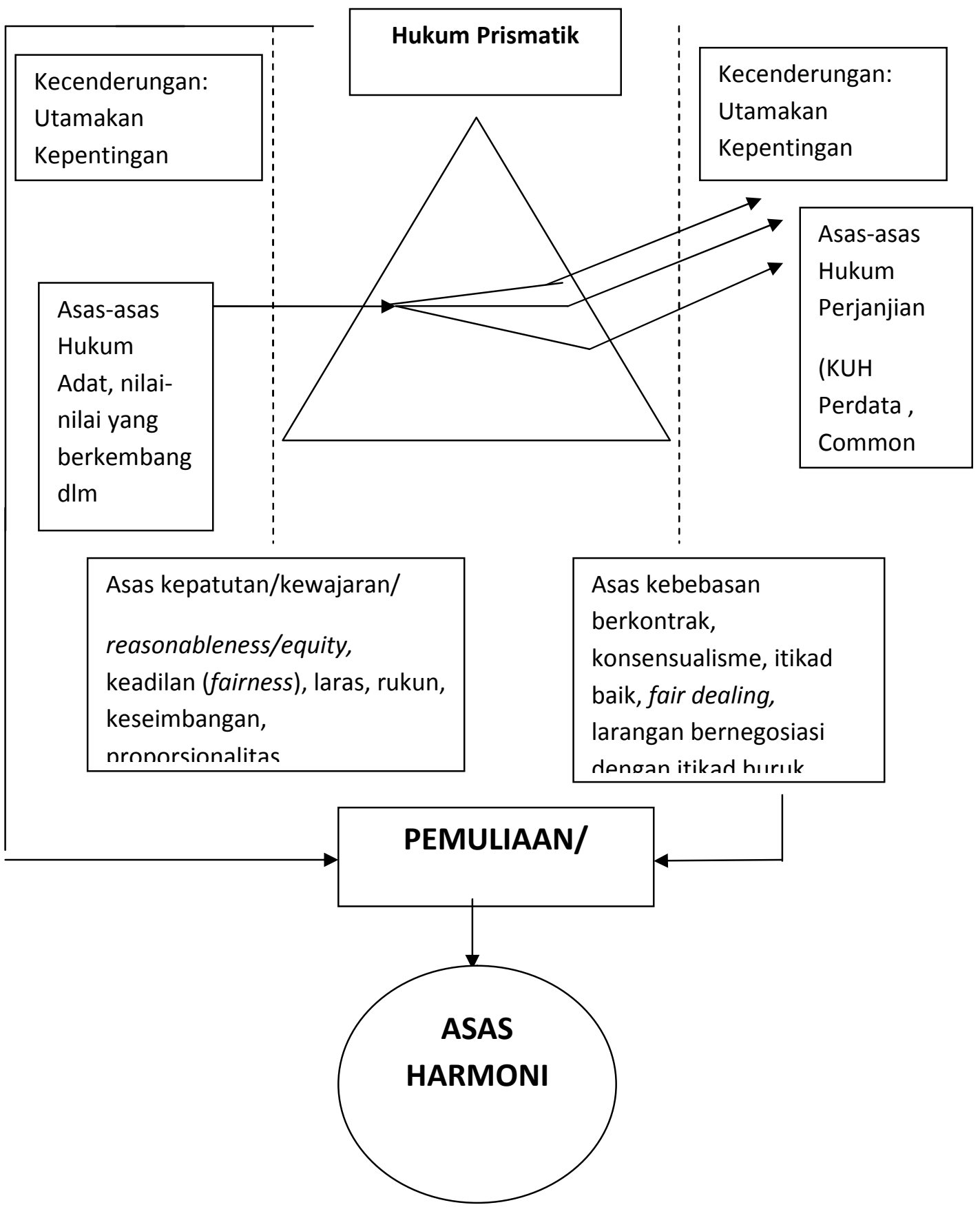


Harmoni dalam kamus Bahasa
Indonesia disamakan dengan
keselarasan. Keselarasan sendiri
berasal dari kata laras yang berarti
harmoni, kesamaan, keserasian,
keteraturan, keterpaduan, kepatutan,
kecocokan, konsisten, kesesuaian,
sebanding, seimbang, sejalan, senada,
senafas, kesetaraan, kewajaran. Asas
harmoni 1 ini merupakan hasil
pengolahan dari asas -asas hukum
perjanjian dengan asas hukum
ekonomi, asas hukum adat, nilai-nilai
yang hidup dalam masyarakat terutama
asas kepatutan, keadilan, laras, rukun,
seimbang, proporsional, yang dapat
menciptakan hubungan hukum yang
seimbang antara para pihak. Asas
harmoni ini berkaitan dengan seluruh
proses perjanjian dan substansi
perjanjian, serta membentuk jalinan
dan mengharmonisasikan asas-asas
hukum perjanjian yang telah ada yang
meliputi asas konsensualisme, asas
kebebasan berkontrak, asas kekuatan
mengikat perjanjian, sehingga
perjanjian tidak hanya bersifat yuridis,
tetapi juga sosiologis, filosofis, yang
tidak hanya memperhatikan aspek
materiil tetapi juga berdimensi moral
religius. Dalam hal demikian
perjanjian tidak hanya didasarkan pada
hukum negara (state law) tetapi juga
hukum alam (natural law/moral/agama), serta hukum yang hidup di dalam masyarakat (the living law). Pendekatan hukum dilakukan dengan pendekatan legal pluralism yang menyatukan pendekatan filosofis, yuridis, socio legal. Cara berhukum demikian sangat tepat dikatakan sebagai cara berhukum yang progresif yang mendasarkan pandangan bahwa hukum adalah untuk manusia, sehingga keberadaan hukum adalah untuk kebahagiaan masyarakat, hukum harus bisa mewujudkan keseimbangan antara nilai-nilai Ketuhanan (moral religius), kemanusiaan (humanistik) kemasyarakatan (nasionalistik, demokratik dan keadilan sosial).
Asas harmoni yang dimaksudkan dalam hal ini merupakan integrasi dari berbagai asas hukum perjanjian dan asasasas hukum lain setidaknya terdiri dari asas-asas sebagai berikut:

1. Asas itikad baik, yang oleh PL. Wery diartikan sebagai redelijkheid dan billjikheid (keadilan/fairness dan kepatutan/reasonableness/equity).

Asas itikad baik ini terdapat dalam KUH Perdata, UNIDROIT Principle (asas itikad baik/good faith) dan transaksi wajar/jujur (fair dealing), larangan bernegosiasi dengan itikad buruk. Keadilan menurut pandangan Al-Ghazali merupakan kualitas jalan tengah/jalan emas untuk menuju jalan keadilan, merupakan kesempurnaan dari segala kebajikan yang berdiri atas equilibrium (keadaan seimbang) dan sikap moderat dalam tingkah laku pribadi dan urusan-urusan publik. Yang terpenting, keadilan merupakan sikap kewajaran (inshaf) yang mendorong manusia untuk menempuh jalan keadilan yaitu jalan yang benar berdasar atas mana manusia mencapai kebahagiaan di dunia dan akhirat. Kebajikan tersebut mencakup kebijaksanaan, keberanian, kesederhanaan dan keadilan. Dengan merujuk pada pengertian itikad baik menurut PL. Wery, maka asas patut tercakup dalam hukum adat sebagaimana dikemukakan Koesnoe, menurut pandangan penulis juga tercakup dalam pengertian asas itikad baik.

2. Asas laras dan rukun, sebagaimana dikemukakan oleh Koesnoe. Asas laras mengandung pengertian adanya keserasian, keteraturan, keterpaduan, kepatutan kecocokan, konsisten, kesesuaian, sebanding, seimbang, sejalan, senada, senafas, kesetaraan, kewajaran. Asas rukun menurut pendapat penulis sejalan dengan asas persatuan, demokratis, keadilan sosial. Dalam hal ini mengandung pengertian musyawarah untuk mencapai mufakat (konsensus), sehingga dalam hal ini terdapat asas persatuan, kebersamaan.

3. Asas keseimbangan, merupakan kualitas jalan tengah dari berbagai

Pemuliaan (Breeding) Asas-Asas... 
kebajikan sebagaimana dikemukakan Al-Ghazali di atas.

4. Asas proporsional, yang mengandung pengertian pembagian secara proporsional.

\section{Simpulan}

Dari hasil penelitian dan pembahasan, dapat diambil simpulan sebagai berikut:

1. Hubungan hukum antara para pihak dalam perjanjian leasing antara lessor dengan lessee yang berkembang di dalam masyarakat menunjukkan adanya ketidakseimbangan dan penyimpangan yang meliputi:

a. Penyimpangan yang bersifat filosofis yaitu penyimpangan terhadap asas-asas hukum perjanjian, baik terhadap asas konsensualisme, asas kebebasan berkontrak maupun asas pacta sunt servanda.

b. Penyimpangan yang bersifat yuridis yaitu penyimpangan terhadap prinsip-prinsip leasing yang terlihat dari: 1) proses perjanjian menunjukkan adanya ketidakseimbangan ; 2) bentuk perjanjian leasing yang berbentuk stándar sehingga bersifat take it or leave it yang menunjukkan adanya ketidakseimbangan; 3) substansi perjanjian yang menunjukkan adanya ketidakseimbangan; 4) penerapan jaminan fidusia yang tidak sesuai dengan prinsip jaminan fidusia;

c. Penyimpangan yang bersifat sosiologis yang meliputi: 1) ketidakseimbangan hubungan hukum antara lessor dengan lessee; 2) ketidakseimbangan bargaining positition ; 3) pengawasan pemerintah kurang memadai; 4) campur tangan negara belum maksimal belum menjangkau pengawasan perjanjian leasing, 5) Kerancuan perjanjian leasing dengan perjanjian lain yang mirip dengan leasing terutama pembiayaan konsumen (consumer finance
Faktor-faktor yang menyebabkan penyimpangan dan ketidakseimbangan tersebut ada berbagai macam yaitu karena perbedaan kepentingan (conflict of interest), perbedaan budaya hukum, perbedaan bargaining position karena perjanjian leasing dibuat dalam bentuk standard, sehingga pihak lessor sebagai pembuat perjanjian telah membuat perjanjian yang lebih menekankan kewajiban lessee daripada haknya, kurangnya pengetahuan para pihak mengenai perjanjian leasing sedangkan undang-undang khusus tentang leasing belum ada.

2. Pemuliaan terhadap asas-asas hukum perjanjian menjadi suatu hal yang urgen yang harus dilakukan agar dalam perjanjian (termasuk perjanjian Leasing) benar-benar dapat tercipta hubungan hukum yang seimbang bagi para pihak, karena dalam praktik leasing yang berkembang di dalam masyarakat terdapat berbagai penyimpangan terhadap asas-asas hukum perjanjian. Adanya penyimpangan asas-asas hukum perjanjian tersebut mengakibatkan ketidakseimbangan hubungan hukum antara para pihak.

3. Pemuliaan terhadap Asas-asas Hukum Perjanjian dilakukan dengan mengintegrasikan asas-asas hukum perjanjian yang diolah dengan asas-asas hukum lain terutama asas hukum ekonomi, asas hukum adat, nilai-nilai yang berkembang di dalam masyarakat dengan berbasis Pancasila sebagai Falsafah Bangsa dan Dasar Negara yang merupakan Hukum Prismatik, sehingga menghasilkan asas hukum prismatik, yang dinamakan asas harmoni.

\section{E. Saran}

1. DPR dan Presiden segera membentuk UU khusus mengenai perjanjian leasing yang berbasis pemuliaan asas-asas hukum perjanjian, agar dalam pratik leasing benarbenar dapat memberikan keseimbangan hubungan hukum antara para pihak, keseimbangan antara individu dan masyarakat.

Pemuliaan (Breeding) Asas-Asas... 
2. Pemerintah sebaiknya membentuk lembaga pengawas khusus untuk mengawasi perjanjian leasing yang berasal dari berbagai Unsur, yaitu pemerintah, tokoh masyarakat dan pengusaha, agar terdapat keseimbangan hubungan hukum antara para pihak.

3. Perusahaan Pembiayaan dan pelaku usaha lain yang mengadakan hubungan hukum leasing sebaiknya mempraktikkan perjanjian berbasis pemuliaan asas-asas hukum perjanjian, serta benar-benar memperhatikan faktor otonom dan heteronom dalam pelaksanaan perjanjian.
4. Pemerintah, masyarakat, pelaku usaha sebaiknya segera mengubah paradigma dalam praktik perjanjian leasing yang semula hanya berorientasi pada aspek ekonomis untuk mendapatkan keuntungan yang sebesar-besarnya bagi kepentingan individu perlu diubah bahwa perjanjian harus dapat menciptakan harmoni antara nilai-nilai Ketuhanan (moral religius), kemanusiaan (humanistik) dan kemasyarakatan (nasionalistik, demokratik, keadilan sosial). 


\section{DAFTAR PUSTAKA}

A.A.G Peters. Koesriani. 1990. Hukum dan Perkembangan Sosial, Buku III. Jakarta: Pustaka Sinar Harapan

Bruggink, J.J.H. 1999. Rechts-Reflecties, diterjemahkan oleh Arief Sidharta dengan judul Refleksi tentang Hukum. Bandung: PT. Citra Aditya Bakti

Lexy J Moleong. 1996. Metodologi Penelitian Qualitatif. Bandung: PT. Remaja Rosdakarya

Lili Rasyidi. 1991. Filsafat Hukum -Apakah Hukum itu ? Cetakan Kelima. Bandung: PT. Remaja Rosdakarya

Manuel G Velasquez. 2005. Etika Bisnis (Konsep dan Kasus), Edisi 5, diterjemahkan dari buku Business Ethics, Concepts dan Cases oleh Ana Purwaningsih, Kurnianto, Totok Budi Santoso. Yogyakarta: Andi

Mariam Darus Badrulzaman. 1980 Perjanjian Baku (Standard), Perkembangannya di Indonesia. Bandung: Alumni 1994. Aneka Hukum Bisnis. Bandung: Alumni

Mattew B Miles and A. Michael Huberman. 1992. Analisis Data Kualitatif., Jakarta: UI Press

Mubyarto. 2002. Ekonomi Pancasila, Landasan Pikir dan Misi Pendirian Pusat Studi Ekonomi Pancasila Universitas Gadjah Mada. Yogyakarta: BPFE

Munir Fuady. 1995. Hukum tentang Pembiayaan dalam Teori dan Praktek, (Leasing, Factoring, Modal Ventura, Pembiayaan Konsumen, Kartu Kredit). Bandung: PT Citra Aditya Bakti

Noeng Muhadjir. 2002. Metodologi Penelitian Kualitatif. Yogyakarta: Penerbit Rake Sarasin

Norman K Denzin dan Y. Vonna S. Lincoln. 1994. Introduction: Entering The Field of Qualitative Research, dalam Norman K. Denzin dan Y. Vonna S. Lincoln. Hand Book of Qualitative Research. California: Sage Publication

P.L.Wery. 1996. "Perkembangan Hukum Tentang Itikad Baik di Nederland”, Ceramah pada Kesempatan merayakan Lustrum II Program Studi Spesialis Kenotariatan pada Fakultas Hukum Universitas Airlangga, di Surabaya. Jakarta: Percetakan RI

Purwahid Patrik. 1998. Perjanjian Baku dan Penyalahgunaan Keadaan”, Seri Dasar Hukum Ekonomi 5, Hukum Kontrak di Indonesia. Jakarta: ELIPS dan Fakultas Hukum Universitas Indonesia

Robert Bogdan \& Steven J Taylor.1993. Dasar-Dasar Penelitian Kualitatif, Penerjemah: A. Khozin Afandi. Surabaya: Usaha Nasional

Ronald Dworkin. 1996. Freedom, Law, The Moral Reading of The American Constitution. Massachusset: Harvard University Press, Chambridge Press

Sanafiah Faisal. 1990. Penelitian Kualitatif: Dasar-dasar \& Aplikasinya. Malang: Yayasan Asah Asih Asuh

Satjipto Rahardjo. 2006. Hukum dalam Jagad ketertiban. Jakarta: UKI Press

Siti Ismijati Jenie. 1992. "Beberapa aspek Yuridis Leasing” Penataran Dosen Hukum Perdata/Dagang 16-28 Nopember/30 Nopember-12 Desember, Yogyakarta: Universitas Gadjah Mada 
1992. "Tinjauan Umum Mengenai Leasing dan Peranannya dalam Usaha Memenuhi Kebutuhan Akan Barang-barang Modal/ Alat-alat Produksi" Penataran Dosen Hukum Perdata/Dagang, 16-28 Nopember /30 Nopember-12 Desember, Yogyakarta: Universitas Gadjah Mada

1998. "Kedudukan Perjanjian Leasing di Dalam Hukum Perikatan Indonesia, Serta Prospek Pengaturan Aspek Hukumnya di Masa Mendatang” Disertasi.Yogyakarta: Universitas Gadjah Mada

Sri Redjeki Hartono. 1995. "Perspektif Hukum Bisnis pada Era Teknologi” Pidato Pengukuhan Guru Besar. Semarang: Fakultas Hukum Undip 2007. Hukum Ekonomi Indonesia. Malang: Bayumedia Publishing

Strauss and Busir J. Corbin. 1990. Qualitative Research; Grounded Theory Procedure and Techniques. London: Sage Publication

Sudikno Mertokusumo. 1990. "Perkembangan Hukum Perjanjian”, Makalah Pada Seminar Nasional Asosiasi Pengajar Hukum Perdata/Dagang 12-13 Maret. Yogyakarta: Fakultas Hukum UGM

1992. “Catatan Kapita Selekta Hukum Perjanjian” Makalah disampaikan pada Penataran Dosen Hukum Perdata/Dagang, 18-20 Nopember/30 Nopember-12 Desember. Yogyakarta: Universtitas Gadjah Mada

1996. Penemuan Hukum Sebuah Pengantar. Yogyakarta: Liberty

1994. Dasar-dasar Hukum Perikatan, Cetakan Pertama. Bandung: Mandar Maju

Sunaryati Hartono. 1991. Politik Hukum Menuju Satu Sistem Hukum Nasional. Bandung: Alumni

Werner Menski. 2006. Comparative Law in A Global Context, The Legal Systems of Asia and Africa, Second Edition. United Kingdom: Cambridge University Press

Wolfgang Friedmann. 1971. The State and The Rule of Law ini a Mixed Economy. London: Stevens and Sons http//id.wikipedia.org, 4 Mei 2009

http//id.wikipedia.org, 2 November 2009

http://investorsukses.ohlog.com, 5 Juni 2009

http://ilmuternak.wordpress.com/animal-breeding/pengantar-ilmu-pemuliaan/diunduh tanggal 4 Mei 2009

http://tutorialkuliah.blogspot.com, Teori Tindakan dan Teori Sistem, 2009.

http//www.ifsa.or.id.history.php, 2 November 2009.

http://wikipedia.or.id, diunduh tanggal 2 Pebruari 201

UUD 1945;

Kitab Undang-undang Hukum Perdata. 
Undang-undang Nomor 7 Tahun 1972 Tentang Perbankan.

Undang-undang Nomor 10 Tahun 1998 Tentang Perubahan Terhadap Undang-undang Nomor 7 Tahun 1992 Tentang Perbankan.

Undang-undang Nomor 8 Tahun 1999 Tentang Perlindungan Konsumen.

Undang-undang Nomor 42 Tahun 1999 Tentang Jaminan Fidusia.

Peraturan Presiden Nomor 9 Tahun 2009 Tentang Lembaga Pembiayaan, tanggal 18 Maret 2009.

Peraturan Menteri Keuangan Nomor 84/PMK.012/2006 Tentang Perusahaan Pembiayaan.

Peraturan Menteri Keuangan Nomor 30/PMK.010/2010 tentang Penerapan Prinsip Mengenal Nasabah.

Surat Keputusan Bersama Menteri Keuangan, Menteri Perindustrian, dan Menteri Perdagangan Nomor: KEP122/MK/IV/2/1974, Nomor: 32/M/SK/2/1974, dan Nomor: 30/Kpb/I/1974 tentang Perizinan Usaha Leasing.

Surat Keputusan Menteri Keuangan Nomor: KEP-649/MK/IV/5/1974 tentang Izin Usaha Leasing.

Keputusan Menteri Keuangan RI Nomor 1169/KMK.01/1991 tentang Kegiatan Sewa Guna Usaha (leasing). 